\title{
Metabolic changes during hibernating period in Indian common toad, Duttaphrynus melanostictus (Schneider, 1799)
}

\author{
Suman Pratihar* and Jayanta Kumar Kundu \\ Molecular Biology Laboratory, Department of Zoology, Vidyasagar University, Midnapore -721102 (West Bengal), INDIA \\ *Corresponding author. E-mail : pratihar_vu@yahoo.co.in
}

\begin{abstract}
The present investigation reports the effect of hibernation on different blood-plasma biochemical parameters viz. plasma protein, plasma glucose and blood urea, thyroid hormone and cholesterol in the Indian Common toad (Duttaphrynus melanostictus). The study indicated that the total plasma protein is decreased significantly in hibernating toads. The decline in thyroid hormone concentration had its behavioral and physiological response that leads to increase and sustain cholesterol level in serum. But plasma glucose was significantly decreased in hibernating toads. During the hibernating phase increased urea concentration in blood acts as cryoprotectant agent, which helps the hibernating animals to sustain in winter. Thus during hibernation these altered metabolic changes appear to be essential for survival.
\end{abstract}

Keywords: Hibernation, Thyroid hormone, Plasma protein, Urea

\section{INTRODUCTION}

Hibernation is a unique phenomenon of depressed metabolism which enables different animals across phyla, particularly anurans to survive during the period of hostile temperature in the winter, when metabolic rate is strongly reduced and the hypothalamic set point for core body temperature is lowered. Hibernation also share the use of specific biochemical mechanism that strongly reduces the net ATP turn over, which changes patterns of fuel use and initiate specific changes in gene expression system (Storey, 2000).

Decrease in environmental temperature in winter acts as cold stress on hibernating toads resulting in slowing down of heart rate, breathing and metabolism so that these animals possess could survive with reserve food. Acclimatization to low temperature causes changes on their system to maintain catalytic potential or to alter the relative activities of different metabolic pathways at low temperature (Hochachka and Somero, 1984). Available reports indicate that environmental cold stress in hibernating toads causes significant changes in plasmaprotein and glucose (Churchill and Storey, 1993; Edwards et al., 2004; Costanzo and Lee, 2005), blood urea ( Jorgenensen, 1997; Costanzo and Lee, 2005 ). Effect of cold stress can also produce remarkable changes in blood urea concentration (Jorgenensen, 1997, Costanzo and Lee, 2005 ,) which probably help the animal to cope with low temperature and act as a cryoprotectent agent.

At the time of the hibernation animals such as anurans enter to a state of hypometabolism when the metabolic rate is suddenly reduced. As they take little or no food during hibernation they depend on their reserve food material which is primarily in the form of fat stored in various tissues. It has been reported that low concentration thyroid hormone help to retain sustained cholesterol level in the blood circulation. The vast majority of the thyroid hormone produced by the thyroid gland is thyroxine (T4). However, T4 has only a slight effect on the metabolic rate. The more active hormone is triiodothyronine (T3). Biologically functional T3 is converted from $\mathrm{T} 4$ in the liver and other tissues by the action of 5-deiodinases (Bolander, 2004).Seasonal variation in the level of thyroid hormone has also been reported among various species (Egeberg and Rosenkilde, 1965; Kuhn et al., 1985; Kar and Chandola-Saklani, 1985 Tasaki et al., 1986 and Sotowska, 2000).The present study deals with the alternative metabolic changes during the hibernation period which help them to cope up with the adverse condition.

\section{MATERIALS AND METHODS}

Ten adult common Indian toads (Duttaphrynus melanostictus), each weighing between 80-100 gm, were collected from a selected site at Midnapur $\left(22^{\circ} 15^{\prime} \mathrm{N} 87^{0} 39^{\prime}\right.$ E), West Bengal India in late October and mid November, 2007 (ambient air temperature $24.4^{\circ} \mathrm{C}$ ) before the onset of hibernation, and second group $(\mathrm{n}=10)$ in mid January (air temperature ranging between $7.4^{\circ} \mathrm{C}-10.2^{\circ} \mathrm{C}$ ) when hibernation was deepest from the mud hole of the same site. Third group $(n=10)$ was collected from the same site 
in late February (air temperature $22^{\circ} \mathrm{C}$ ) when they just aroused from hibernation. Other groups were collected from similar sites throughout the year.

Blood samples were drawn from hibernating and nonhibernating individuals via cardiac puncture using a 21 gauge needle and $5 \mathrm{ml}$ syringe immediately after euthanasia induced by pithing. Blood samples were collected immediately after collection. Animals handling was performed following the ethical guidelines laid down by the committee for the purpose of control and supervision of experimental animals (CPCSEA) constituted by the Animal Welfare Division of Government of India on the use of animals in scientific research.

Blood was transferred to EDTA coated vacutainer tubes for determination of protein, and in sodium floride coated vacutainer tubes for determination of glucose. Plasma was separated by centrifugation $(1500 \times \mathrm{g})$ and the supernatant was taken for biochemical analysis of plasma protein (Lowry et al., 1951), plasma glucose (Kit-MerckDiagonistica-PDLFT0879), serum cholesterol (Nice chemical; S20750), serum T3, T4 (ELISA kit Ranbaxy, Diagnova.1063062, 1063073), blood urea (DAM method, Merck- Diagonistica-PDLFT0082) were analyzed using standard techniques / kits.

\section{RESULTS}

The present study observed that protein and sugar were significantly lower $(\mathrm{P}<0.05)$ in concentration during deep hibernation phase compared that into other phases. On contrary cholesterol concentration was higher during the phase of deep hibernation in the month of January (Fig.1). $\mathrm{T}_{3}$ level changed very little through out the year but $\mathrm{T}_{4}$ level varied significantly $(\mathrm{P}<0.05)$. During hibernating phase (January-February) serum $\mathrm{T}_{4}$ concentration was 8ng/ $\mathrm{ml}$ when air temperature was between $7.4^{\circ} \mathrm{C}-10.2^{\circ} \mathrm{C}$. During rainy season (June-July) it was further increased to $20 \mathrm{ng} / \mathrm{ml}$ (Fig. 2).During the hibernating phase (Jan.), urea conc. was $149.8 \mathrm{mg} / \mathrm{dl}$, (air temperature $7.4^{\circ} \mathrm{c}-10.2^{\circ} \mathrm{c}$ ) It was $130.2 \mathrm{mg} / \mathrm{dl}$ in the month April-May (air temparature $38^{\circ} \mathrm{c}-40^{\circ} \mathrm{c}$ ) when the animal got out from their hibernation. In rainy season (June-July), it was further reduced to $120.6 \mathrm{mg} / \mathrm{dl}$ and at the beginning of winter (OctNov), the urea concentration increased to $134 \mathrm{mg} / \mathrm{dl}$. (Fig.3).

\section{DISCUSSION}

During deep hibernation phase the protein and sugar concentration in plasma were found significantly lower $(\mathrm{P}<0.05)$. In contrast cholesterol concentration was high during this phase. Increased metabolic dependency towards lipids in hibernating condition is not sole response to low temperature but part of circanual homeostatic adjustment that at least partly regulated by thyroid hormone. The decreased serum thyroxin $(8 \mathrm{ng} / \mathrm{ml})$ in the toad suggest that a state of hypometabolism and decreased metabolic rate would allow further conservation of energy during the crucial phase of hibernation. Our result reflects the inverse relationship between serum thyroid hormone level and cholesterol level that has also been reported by Bartley in 1889. Cholesterol 7-alpha hydroxylase (CYP7A) is the key enzyme involved in conversion of cholesterol to bile acid in liver. CYP7A expression was low in hypothyroidism and reactivated when hypothyroidism is reversed with addition of thyroid hormone. Serum cholesterol levels are also elevated during hypothyroidsm and are also reversed when thyroid is added back. CYP7A levels are reduced in hypothyroidism and are directly activated by thyroid hormone (Samyan, 2004). It is evident from the current study that during hibernating period the metabolism is shifted towards lipid dependence and low level of thyroid hormone in that phase result into reduced metabolic rate and additionally helps to sustain high cholesterol level in circulation, which is a must prerequisite for survival of those animals during the hypometabolism state associated with hibernation. Environmental cold stress increases protein catabolism. Plasma protein was significantly less $(\mathrm{P}<0.05)$ in hibernating toads as compared to that in non-hibernating ones as available reports also indicate that cold exposure in winter inhibits the protein synthesis in the blood of Rana pipiens in hibernating season (Churchill and Storey, 1993).

Available reports indicate that urea, the end product of protein metabolism is the predominant organic osmolyte, which accumulates during dehydration in hibernation (Jorgensen, 1997). During the rainy season, urea concentration decreased probably due to their much effect for reproductive success and protein anabolism of the animals. At the beginning of the winter during the months of Oct-Nov (pre-hibernating period) urea concentration further increased $(134 \mathrm{mg} / \mathrm{dl})$ and highest during hibernation. In those month they would probably were making them metabolically competent for the coming harsh winter. Our present findings therefore strongly indicate link between elevated urea level and cryoprotection as indicated by Costanzo and Lee (2005).

It may be concluded that in the common Indian toad decline in thyroid hormone concentration has its behavioral and physiological response that leads to sustain increased cholesterol level in serum, which seems to be the most important metabolite during the hibernating phase. Protein metabolism and elevated urea level plays a significant role in maintaining their physiological status steady particularly during hibernating period. Seasonal variation in urea level is also related to the availability of their food and is a part of metabolic strategy. 


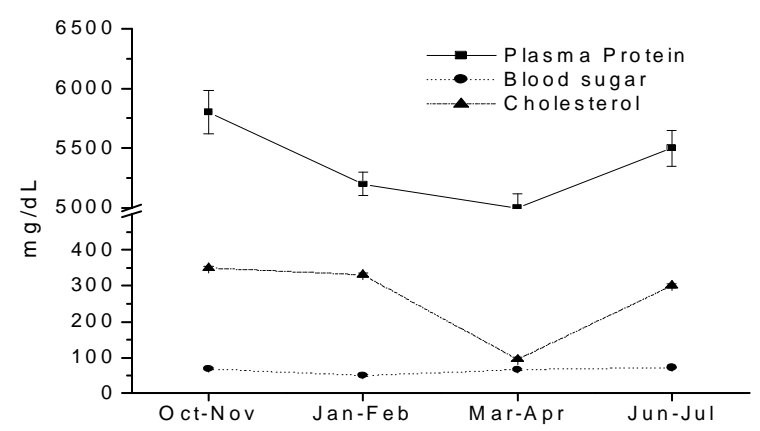

Fig. 1. Showing changes in serum protein, sugar and cholesterol levels $(\mathrm{mg} / \mathrm{dl})$ during various phases of hibernation: before hibernation (Oct-Nov), deep hibernation (Jan-Feb) and after the hibernation (Mar-Apr) and rainy season (Jun-Jul).

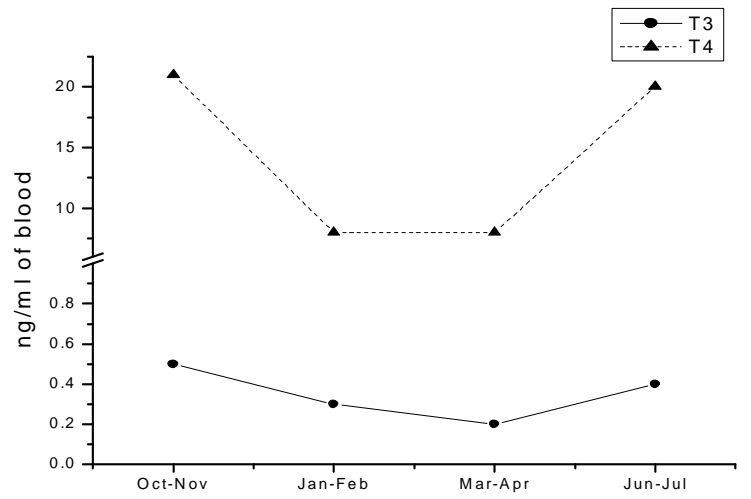

Fig. 2. Showing changes in serum $\mathrm{T} 3$ and $\mathrm{T} 4$ levels (ng/dl) during different phases of hibernation: before hibernation (OctNov), deep hibernation (Jan-Feb) and after the hibernation (Mar) and rainy season (Jun-Jul).

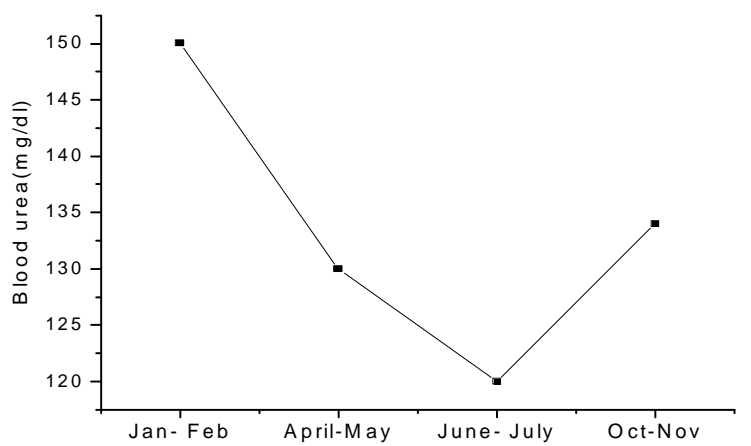

Fig. 3. Showing blood urea concentration in different seasons.

\section{REFERENCES}

Bartley, J.C. (1889). Lipid metabolism and its disease Clinical biochemistry of domestic animals. $4^{\text {th }}$ edition. Academic press, (pp 106-141) New York, USA.

Bolander, F.F. Jr. (2004). Molecular endocrinology. ${ }^{3 r d}$ edition.Academic press. California, USA.

Churchill, T.A. and Storey, K.B. (1993). Dehydration tolerance in wood frogs: a new perspective on development of amphibian freege tolerance. American Journal of Physiology, 265:1324 - 1332 .

Costanzo, J.P. and Lee, R.E. (2005). Cryoprotection by urea in a terrestrially hibernating frog. Journal of Experimental Biology, 208: 4079-4089.

Edwards, J.R., Jenkins, J.L. and Swanson, D.L. (2004). Seasonal effects of dehydradation on glucose mobilization in freeze tolerant Chorus frogs ( Pseudacris triseriata). Journal Experimental Zoology, 301A: 521-531.

Egeberg, J.C. and Rosenkilde, P. (1965). Iodine uptake and ultrastructure of thyroid gland in the cold exposed toads Bufo bufo. General and Comperative Endocrinology, 5: 673.

Hochachka ,P.N. and Somero, G.N. (2002). Biochemical adaption. Oxford University Press, New York.

Jorgensen, C.B. (1997). Urea and amphibian water economy. Comp. Biochem. Physiol. A, 117: 161-170

Kar, A. and Chandola-Saklani, A. (1985). Circulating thyroid hormone concentration in relation to seasonal events in the male Indian garden ligard Calotes, General and Comparative Endicrinology, 60: 14-19.

Kuhn, E. R., Durras, V. M. and Verlinden,T.M.(1985). Annual variations of thyroid reactivity following thyrotropin stimulation and circulation levels of thyroid hormones in the frog Rana ridibunda. General and Comparative Endocrinology, 57:266-273.

Lowry, O.H., Brough, N.J.R., Farr, A.L. and Randall, R.J. (1951). Protein measurement with the Folin phenol reagent. J. Biol. Chem. 193:265-275.

Sotowska Powe Kowalczyk Jolanta. (2000). Changes in thyroid hormones in the serum and the thyroid gland of hibernating frogs Rana temporaries. General and Comparative Endocrinology,119: 172-180.

Samyan Saro (2004). Thyroid hormone directly regulates cholesterol -7 Alpha Hydroxylase (CYP7A) gene expressions through a thyroid receptor binding site in the CYP7A promoter. Retrieved on 22.09.2008, www. due.vci edu/urop/ symp2004-Sping/62 125 versions 1.

Storey, K.B. (2000). "Turning down the fire of life; Metabolic regulation of hibernation and estivation," (pp 1-2) Bios scientific publication, Oxford.

Tasaki, Y., Inove, M. and Isii, S. (1986). Annual cycle of plasma thyroid hormone levels in the toad, Bufo japonica, General and Comparative Endocrinology, 62:404-410. 